\title{
De bemoedigende houding
}

Een belangrijke aanvulling op Strawsoniaanse theorieën van verantwoordelijkheid

Daphne Brandenburg

ANTW 110 (4): 405-420

DOI: $10.5117 /$ ANTW2018.4.002.BRAN

\section{Abstract \\ The Nurturing Stance. A critical addition to Strawsonian theories of responsibility.}

In this paper I provide an important addition to Strawsonian theory. In the first section I briefly discuss the Strawsonian approach to responsibility. Then I discuss in some detail the stance we, according to Strawsonians, take towards people who lack the abilities to comply with moral norms. This 'objective stance' is inconsistent with the stance that is considered typical and desirable in psychiatric contexts and care-relationships more generally speaking. In order to resolve this conflict I formulate an additional stance that allows Strawsonian theory to account for this.

Keywords: responsibility, Strawson, moral agency, objective stance, nurturing stance

\section{$1 \quad$ Inleiding}

Wanneer en waarom mogen we elkaar verantwoordelijk houden voor het overschrijden van een morele norm? Filosofen steggelen al eeuwen over het juiste antwoord op deze vraag. Centraal in dit debat is het conflict tussen filosofen die beweren dat we iemand verantwoordelijk mogen houden wanneer dit wenselijke consequenties heeft, en filosofen die beweren dat we iemand verantwoordelijk mogen houden wanneer diegene uit vrije wil heeft gehandeld en het daarom verdient. 
Een populaire stroming in het huidige debat probeert aan dit conflict voorbij te gaan door te kijken naar onze emoties in reactie op normoverschrijdingen. Deze stroming is gebaseerd op een argument van P.F. Strawson (Strawson 1962). Volgens Strawson zijn er onvolkomenheden in zowel het vrije wil kamp als in het consequentialistische kamp. Verdienste wordt in het eerste kamp gebaseerd op een vorm van vrije wil die in ons universum simpelweg niet bestaat. Maar het consequentialische argument beroept zich slechts op de efficiëntie van verantwoordelijkheidspraktijken. Efficiëntie lijkt een onvolledig en soms tegen-intuïtief antwoord op de vraag waarom we elkaar verantwoordelijk mogen houden.

We kunnen volgens Strawson het juiste midden tussen deze twee kampen vinden door te kijken naar onze menselijke betrokkenheid op elkaar. Mensen hechten over het algemeen veel waarde aan de houding die anderen ten opzichte van ons hebben, en onze houding ten opzichte van anderen hangt in grote mate af van hoe zij ons erkennen en respecteren. Volgens hem speelt deze menselijke betrokkenheid op elkaar een centrale rol in waarom we anderen verantwoordelijk houden voor norm-overschrijdingen. Wanneer je buurman bijvoorbeeld iedere keer zijn auto voor je oprit parkeert, terwijl je hem er meerdere malen op hebt gewezen dat je dan zelf niet naar je werk kunt rijden, zal je geneigd zijn om wrokkige gevoelens jegens je buurman te ontwikkelen. En vanuit een derdepersoonsperspectief zou het niet vreemd zijn wanneer we verontwaardigd zijn over het gedrag van deze buurman.

Wat dit laat zien is dat het ons raakt wanneer iemand de morele normen van een samenleving op deze manier overschrijdt. We vinden verontwaardiging daarbij een gepaste reactie wanneer de dader geen goed excuus kan geven voor zijn gedrag en verder de gemiddelde competenties heeft om aan de normen van onze samenleving te voldoen. Misschien had de buurman deze keer alleen even snel geparkeerd omdat hij zijn tas was vergeten. Of misschien is er iets mis met zijn kortetermijngeheugen. Maar in de afwezigheid van dergelijke overwegingen, is verontwaardiging gepast. Deze affectieve reactie op moreel onwenselijk gedrag is volgens Strawsonianen een essentieel kenmerk van wat het betekent om iemand moreel verantwoordelijk te houden voor het overschrijden van een norm.

Hoewel deze interpersoonlijke emotionele betrokkenheid ook goede consequenties kan hebben in termen van morele educatie en moreel herstel, zijn deze consequenties volgens Strawson geen goede redenen voor het voelen van verontwaardiging in reactie op het gedrag van de ander. We voelen deze emotionele betrokkenheid niet omdat het nuttig of strategisch is om je zo te voelen. We hebben gegronde redenen voor het voelen van 
verontwaardiging jegens de ander wanneer hij of zij iemand slecht heeft behandeld zonder zich daarbij te kunnen beroepen op uitzonderlijke omstandigheden of beperkte vaardigheden. Wanneer de ander een kind is, of actief psychotisch is, zullen we hem of haar typisch niet verantwoordelijk houden voor het overschrijden van een norm en zijn gevoelens van verontwaardiging ook ongepast.

Maar de gemiddelde volwassene heeft voldoende capaciteiten om de morele normen van onze gemeenschap na te leven. Deze gemiddelde vaardigheden volstaan volgens Strawson voor onze verantwoordelijkheidspraktijken, en we hoeven ons dus niet te beroepen op een vorm van vrijheid die in onze wereld niet kan bestaan. Zijn theorie geeft ons zo een antwoord op de vraag waarom we iemand verantwoordelijk mogen houden dat niet te reduceren valt tot efficiëntie maar ook niet afhangt van een onwerkelijke vorm van vrije wil.

Er zijn verschillende interpretaties wanneer het aankomt op de precieze manier waarop Strawson's argument aan het klassieke conflict voorbij gaat (Hieronymi 2016; McKenna 2012; McKenna \& Russell 2008; Shoemaker 2015). Er zijn bovendien ook filosofen die beargumenteren dat Strawson er niet in is geslaagd om aan het klassieke conflict voorbij te gaan (Pereboom 2001; Todd 2016). Ik wil deze discussie hier parkeren. In dit stuk zal ik de Strawsoniaanse theorie op andere gronden bevragen. Ik bevraag of zijn theorie de juiste implicaties heeft voor onze betrokkenheid op mensen wiens capaciteiten om aan onze morele normen te voldoen onder het gemiddelde vallen. Ik bespreek nu eerst in meer detail wat Strawsonianen precies zeggen over onze houding ten opzichte van mensen wiens morele vaardigheden onvoldoende zijn om aan de morele normen en verwachtingen van onze gemeenschap te kunnen voldoen. In de rest van het artikel bevraag ik dit aspect van de Strawsoniaanse theorie.

\section{De objectieve stance}

Strawson spreekt zich niet alleen uit over hoe en waarom we gemiddeld competente deelnemers binnen een samenleving verantwoordelijk mogen houden. Het is voor zijn argument ook belangrijk dat het verantwoordelijk houden van een ander ongepast is wanneer iemand er onvoldoende toe in staat is om aan de heersende morele normen van een gemeenschap te voldoen.

Er zijn verschillende overwegingen die ons reden geven om onze attitudes aan te passen of te verzachten. Ondanks de grote variëteit van 
dergelijke overwegingen kunnen we ze, volgens Strawson, grofweg in twee types indelen. Belangrijk voor zijn argument en voor mijn analyse hier, zijn het tweede type overwegingen. Strawson schrijft dat deze klasse van overwegingen 'allows that the circumstances were normal, but presents the agent as psychologically abnormal - or as morally undeveloped. The agent was himself; but he is warped or deranged, neurotic or just a child. When we see someone in such a light as this, all our reactive attitudes tend to be profoundly modified' (Strawson 2008: 9). Hij beschrijft vervolgens hoe we tegenover deze individuen de neiging hebben om een bepaalde 'objectieve houding' in te nemen. Volgens hem is deze houding zowel de meest natuurlijke als de meest beschaafde reactie.

Strawson beschrijft deze objectieve houding als volgt:

[I]t may include repulsion or fear, it may include pity or even love, though not all kinds of love. But it cannot include the range of reactive feelings and attitudes which belong to involvement or participation with others in inter-personal human relationships; it cannot include resentment, gratitude, forgiveness, anger, or the sort of love which two adults can sometimes be said to feel reciprocally, for each other. If your attitude towards someone is wholly objective, then though you may fight him, you cannot quarrel with him, and though you may talk to him, even negotiate with him, you cannot reason with him. You can at most pretend to quarrel, or to reason, with him. (2008:10)

In het moderne debat zeggen veel filosofen iets soortgelijks over mensen die (nog) niet aan onze morele normen kunnen voldoen. De Stanford encyclopedia meldt dat, volgens de Strawsoniaanse positie, men in deze gevallen 'ceases to regard the individual as capable of participating in genuine personal relations (either for some limited time or permanently). Instead, one regards the individual as psychologically/morally abnormal or undeveloped and thereby a candidate, not for the full range of reactive attitudes, but primarily for those objective attitudes associated with treatment or simply instrumental control. Such individuals lie, in some sense or to some varying extent, outside the boundaries of the moral community' (Eshleman 2016).

De meeste Strawsonianen beweren dus dat wanneer iemand niet aan de heersende morele normen en verwachtingen kan voldoen, we typisch geen verwijtende reactie zouden moeten hebben wanneer diegene een norm overschrijdt en beter een objectieve houding in kunnen nemen van waaruit we niet met hem of haar kunnen discussiëren of ruziemaken betreffende de overschrijding van deze norm. We houden diegene dan in het geheel niet verantwoordelijk op het moment dat zij bepaalde normen 
overschrijdt, en zien haar, in het licht van deze normen, meer als een object dat we moeten managen en controleren. Behalve een typische reactie is dit volgens de meeste Strawsonianen ook een wenselijke reactie (e.g. McKenna 2012; Shoemaker 2015).

In de rest van dit stuk bevraag ik deze claims. Ik bespreek eerst hoe mensen die (nog) niet kunnen voldoen aan een morele norm, toch - op een bepaalde manier - verantwoordelijk worden gehouden. Daarna bespreek ik hoe deze vorm van verantwoordelijk houden implicaties heeft voor de Strawsoniaanse theorie.

\section{Praktijken in de psychiatrie: verantwoordelijkheid zonder verwijt}

Wanneer iemand niet goed kan begrijpen dat ze schade aanricht, of onvoldoende zelf-controle heeft over zijn of haar gedrag, vinden we meestal dat de persoon niet laakbaar is voor het aanrichten van deze schade. Dergelijke overwegingen lijken te behoren tot het type overweging dat hierboven werd bediscussieerd. Hoewel de omstandigheden in dergelijke gevallen normaal zijn, zijn de psychologische capaciteiten van de persoon abnormaal. En het zijn deze psychologische factoren die verklaren waarom we de persoon in kwestie de aangedane schade in dergelijke gevallen niet mogen verwijten en nadragen. Dit zou ook betekenen, volgens de Strawsonianen, dat we beter een 'objectieve houding' kunnen innemen ten opzichte van deze persoon wanneer het aankomt op de normen die ze niet kunnen naleven.

Maar is dit daadwerkelijk wat we doen en wat we zouden moeten doen? Wanneer we kijken naar de manier waarop clinici of andere zorgverleners omgaan met mensen die norm-overschrijdend gedrag vertonen, zien we van deze objectieve houding vaak maar weinig terug. Hannah Pickard beschrijft bijvoorbeeld hoe, in de kliniek waar ze werkt, clinici meestal geen verwijtgevoelens ervaren en uiten wanneer de patiënt morele normen overschrijdt, maar een patiënt wel verantwoordelijk houden (Pickard 2013). Stel je bijvoorbeeld voor dat een patiënt tijdens een gezamenlijke maaltijd totaal de controle verliest en een bord door de ruimte kapot gooit. Zulk gedrag is natuurlijk moreel problematisch. De scherven kunnen de andere patiënten lichamelijk letsel aanbrengen en de agressie is op zichzelf intimiderend en verziekt de sfeer. Morele normen worden hier dus overschreden. Maar in reactie op dergelijk gedrag zal een clinicus in haar kliniek waarschijnlijk geen verwijtgevoelens ervaren en uiten. In plaats daarvan zullen ze, wanneer de patiënt bedaard is, met haar een gesprek aangaan waarin ze 
bijvoorbeeld zoiets zeggen als: ik begrijp dat je erg overstuur was, maar deze reactie is onacceptabel hier. Je brengt jezelf en anderen daarmee in gevaar. Wat ga je doen om te zorgen dat dit niet weer gebeurt? En wat heb je daarbij van ons nodig? Iets soortgelijks geldt bijvoorbeeld wanneer een patiënt zich niet aan de afspraken van een behandelingsplan houdt. In reactie zal een clinicus dit de patiënt niet verwijten, maar eerder zoiets zeggen als: je weet dat dit plan belangrijk is en we hebben het samen opgesteld, hoe kunnen we ervoor zorgen dat je je in de toekomst aan onze afspraken houdt?

Deze reacties zijn een vorm van verantwoordelijk houden. De patiënt wordt duidelijk niet geheel geëxcuseerd voor zijn of haar gedrag. De patiënt wordt daarbij ook niet slechts gezien als iemand die 'gemanaged' of gecontroleerd moet worden. Het belang van de morele normen wordt aan de patiënt voorgelegd en de clinicus doet daarbij een beroep op de autonomie van de patiënt. Maar deze vorm van verantwoordelijk houden staat los van emotioneel verwijt. De clinicus voelt geen verontwaardiging jegens de patiënt en zegt bijvoorbeeld niet tegen de patiënt dat zijn gedrag respectloos en onachtzaam was en oordeelt ook niet dat de persoon in kwestie nalatig was, of zelfs kwade intenties had.

Volgens Pickard zouden verwijtgevoelens jegens de persoon in dergelijke gevallen ook onterecht zijn. Binnen de kliniek, zo zegt ze, houden clinici mensen verantwoordelijk voor moreel onwenselijk gedrag, maar wordt hen dit gedrag niet in emotionele zin verweten. We zien volgens haar dus een vorm van verantwoordelijkheid zonder emotioneel verwijt in plaats van een objectieve houding (Pickard, 2013). Meer in het algemeen denk ik dat we een dergelijke reactie ook vinden in een breder scala aan zorgrelaties. In onze omgang met mensen die nog niet aan (alle) morele normen kunnen voldoen vinden we vaak een midden tussen verwijt en algehele uitzondering van verantwoordelijkheid.

Pickard claimt dat de patiënten in kwestie wel de capaciteiten hebben om aan morele normen te voldoen en ook laakbaar zijn voor het niet naleven van die normen, maar toch geen verwijtgevoelens verdient (Pickard, 2015). Ik heb elders in detail bekritiseerd waarom Pickard's eigen antwoord op deze vraag problematisch is (Brandenburg, 2017). Ik ben ervan overtuigd dat sommige van de patiënten uit haar voorbeelden echt geen verwijtgevoelens verdienen en daarbij ook niet laakbaar zijn voor het overschrijden van een morele norm, omdat ze nog niet aan deze normen kunnen voldoen. Toch is er, volgens mij, wel degelijk een manier waarop we hen verantwoordelijk kunnen en mogen houden.

Dit staat op gespannen voet met de Strawsoniaanse theorie. Iemand verantwoordelijk mogen houden voor het aanrichten van morele schade gaat, 
volgens Strawson, simpelweg hand in hand met de gepastheid van verwijtgevoelens jegens die persoon. En hoewel we soms goede redenen kunnen hebben om die gevoelens voor onszelf te houden en het ook weer niet zo is dat we deze gevoelens moeten hebben (e.g. Wallace, 1996), kunnen we binnen deze theorie niet zeggen dat een gevoel van verontwaardiging ongepast is wanneer iemand daadwerkelijk morele verantwoordelijkheid draagt voor het overschrijden van een norm. Tegelijkertijd is het zo dat, als gevoelde verontwaardiging wel ongepast is, dit ook betekent dat de persoon juist niet moreel verantwoordelijk was voor het overschrijden van een morele norm. En op dat moment lijkt het dan weer vreemd dat we de persoon toch verantwoordelijk mogen houden, terwijl hij of zij geen morele verantwoordelijkheid draagt. Hoe kunnen we dan, binnen een Strawsoniaanse theorie, uitleggen dat we iemand soms wel verantwoordelijk mogen houden, terwijl deze persoon niet laakbaar is en geen verwijtgevoelens verdient? Op deze vraag kan een antwoord geformuleerd worden door eerst beter te kijken naar wat we precies bedoelen wanneer we zeggen dat iemand aan morele normen kan voldoen.

\section{Kunnen in de potentiële zin van het woord}

Het woord 'kunnen' is ambigu. Vergelijk bijvoorbeeld de volgende zinnen:

(1) je kunt lopen

(2) je kunt je beperken tot één glas bier

(3) je kunt een berg beklimmen

(4) je kunt je rijbewijs halen

Zinnen zoals (1) en (2) verwijzen meestal naar iets dat de meeste mensen 'gewoon kunnen', terwijl zinnen zoals (3) en (4) ook kunnen verwijzen naar iets dat mensen als het ware 'in zich hebben'. Ze kunnen deze dingen misschien nu nog niet, maar met de nodige hulp en ontwikkeling kunnen ze het wel. De tweede zinnen worden vaak op een bemoedigende manier uitgesproken. Je kunt die berg beklimmen! En je kunt je rijbewijs halen! Het is meestal onjuist om tegen iemand te zeggen dat ze haar rijbewijs niet kan halen, omdat je daarmee suggereert dat iemand het zowel nu als in de toekomst niet zal kunnen. Meestal is dat echter niet het geval. Hoewel iemand zonder lessen zijn rijbewijs nog niet kan halen, kan diegene het wel wanneer ze voldoende les heeft gehad.

Laakbaarheid voor het overschrijden van een morele norm vereist dat je iets kunt in de directe zin van het woord. Stel je bijvoorbeeld voor dat 
een kleine gemeenschap, om zichzelf te voorzien van voedsel, bessen moet halen aan de andere kant van het bos. Het vereist een kleine wandeling om die bessen te plukken. De meeste leden van deze gemeenschap kunnen wandelen en het wordt van hen dan ook verwacht dat ze evenveel tijd steken in de voedselvoorziening. Degene die dit zonder goede opgaaf van reden toch weigert te doen, zal dit op de verontwaardiging van de andere groepsleden komen te staan.

Maar stel je nu voor dat deze gemeenschap in plaats daarvan een berg moet beklimmen. Het is nu waarschijnlijk dat de leden van deze gemeenschap eerst moeten leren om een berg te beklimmen. Lopen vereist minder ontwikkeling en training dan het beklimmen van een berg. Bovendien zal niet ieder lid al even goed in staat zijn om een berg te beklimmen en zal ook niet iedereen even snel zijn in het leren te beklimmen van een berg.

Hoewel het in deze gemeenschap ook een morele norm is dat mensen de lasten van het bergbeklimmen verdelen, wordt nu niet van iedereen in gelijke mate verwacht dat ze de berg beklimmen en voedsel halen. Het wordt alleen verwacht van de mensen die al kunnen klimmen; alleen deze mensen zijn laakbaar wanneer ze geen voedsel halen. De mensen die alleen in potentiële zin een berg kunnen beklimmen zijn niet laakbaar wanneer ze geen voedsel halen op de berg. Maar dat betekent niet dat mensen die nog geen bergen kunnen beklimmen op geen enkele manier verantwoordelijk mogen worden gehouden binnen deze gemeenschap. Omdat het in het belang van iedereen in de gemeenschap is om zoveel mogelijk voedsel te halen, wordt van deze laatste mensen verwacht dat ze zich inzetten om te leren hoe ze een berg moeten beklimmen. Ze zijn dus niet volledig uitgezonderd van verantwoordelijkheid voor het beklimmen van bergen. Er wordt niet van hen verwacht dat ze $n u$ aan deze normen kunnen voldoen, maar er wordt wel verwacht dat ze zich inzetten om te leren om aan deze normen te kunnen voldoen.

Wanneer we dit verhaal toepassen op de patiënten die Pickard voor ogen heeft, zien we hoe het mogelijk is om iemand verantwoordelijk te houden zonder dat diegene laakbaar is voor het overschrijden van een morele norm. Ik vermoed dat wanneer Pickard zegt dat mensen die bijvoorbeeld verslaafd zijn, wel degelijk kunnen stoppen te gebruiken en hun problematische gedragspatronen kunnen doorbreken, dat ze (meestal) 'kunnen' in een meer potentiële zin van het woord bedoelt. Voor veel patiënten geldt dat ze kunnen leren om, bijvoorbeeld, hun verlangens en stress beter te managen, en zich te weerhouden van alcoholmisbruik.

De meeste mensen buiten een psychiatrische context kunnen dit op de manier zoals dat bedoeld is in zin (1) en (2): ze kunnen dat nu gewoon al 
zonder daar nog verdere vaardigheden voor te hoeven ontwikkelen en hulp bij nodig te hebben. Maar voor patiënten in een psychiatrische kliniek geldt vaak dat ze dergelijke dingen kunnen zoals dat bedoeld is in zin (3) en (4): met de nodige hulp en inzet kunnen ze situaties beter leren inschatten en zichzelf beter leren controleren.

Wanneer een patiënt geld heeft gestolen om zijn eigen verslaving te onderhouden, kan het goed zijn dat ze deze verslaving nog onvoldoende onder controle heeft. Wanneer we er hier even van uit gaan dat deze patiënt ook niet verantwoordelijk is voor het verslaafd raken in de eerste plaats - omdat ze bijvoorbeeld al verslaafd raakte als kind - dan zouden we kunnen zeggen dat ze niet laakbaar is voor het stelen van geld. Maar dat betekent niet dat we de patiënt op geen enkele manier verantwoordelijk kunnen houden. De patiënt heeft het wel 'in zich' om deze gedragspatronen te doorbreken en eigendom van anderen te respecteren.

In dit geval zou ik zeggen dat we de patiënt niet laakbaar mogen achten voor de aangedane schade, maar haar wel verantwoordelijk mogen houden. We mogen haar verantwoordelijk houden in de zin dat we een beroep mogen doen op haar capaciteiten om te leren hoe ze beter rekening kan houden met de belangen van een gemeenschap en zichzelf kan leren te controleren in het licht van deze belangen. Deze houding lijkt ook gepast wanneer bijvoorbeeld iemand met autisme een hele botte opmerking maakt zonder deze botheid goed te begrijpen, of wanneer iemand met onbehandelde borderline verbaal uithaalt nadat ze emotioneel overprikkeld raakt.

Mijn antwoord op de vraag hoe en waarom we iemand die niet laakbaar is toch verantwoordelijk mogen houden wanneer diegene een norm overschrijdt, is dus dat we, in reactie op een dergelijke normoverschrijding, een beroep mogen doen op iemands capaciteiten om zichzelf zodanig te ontwikkelen dat ze in de toekomst aan deze normen kan voldoen. Zeker binnen een zorgcontext geldt hierbij natuurlijk dat we die persoon ook de hulp en ondersteuning bieden die hij of zij daarbij nodig heeft.

We kunnen iemand op deze manier verantwoordelijk houden omdat er een onderscheid valt te maken tussen iets überhaupt niet kunnen, iets nu nog niet kunnen maar wel 'in je hebben', en iets al kunnen. In het eerste geval is iemand niet verantwoordelijk, in het tweede geval draagt iemand als lid van een morele gemeenschap een bepaalde verantwoordelijkheid om te leren zich aan morele normen te houden, en in het laatste geval draagt iemand de volledige verantwoordelijkheid om al aan morele normen te voldoen. 
Dit onderscheid is natuurlijk niet alleen een onderscheid tussen normoverschrijdingen in een klinische setting en die daarbuiten. Soms kan een patiënt prima morele normen naleven en worstelt ze juist met andere niet-moreel gerelateerde problemen (McKenna \& Kozuch 2015). En soms kunnen mensen buiten de kliniek juist nog niet aan morele standaarden voldoen zonder dat ze daarbij gediagnosticeerd kunnen worden met een mentale aandoening.

Maar het is geen verrassing dat we deze problematiek veel zien in psychiatrische klinieken. Patiënten in de psychiatrie hebben vaak te maken met een achtergrond waarbinnen men makkelijk verkeerde gedragspatronen aanleert en weinig handvaten krijgt voor het leren beheersen en sturen van bijvoorbeeld agressie of stress. Daarbij kan ook de mentale aandoening zelf het herkennen en naleven van morele normen soms problematiseren. Dit moeten we in acht nemen wanneer we ons afvragen of we een patiënt verantwoordelijk mogen houden voor het overschrijden van een norm.

\section{$5 \quad$ De bemoedigende houding}

De potentiële zin van kunnen helpt ons om een houding te formuleren die verschilt van de objectieve houding en van een verwijtende houding. Ik noem deze houding de bemoedigende houding. Deze houding is een belangrijke aanvulling op de theorie en zorgt ervoor dat Strawsonianen beter kunnen uitleggen hoe we omgaan en zouden moeten omgaan met mensen die wel de potentie hebben om bepaalde morele normen na te kunnen leven, maar nog niet voldoende vaardigheden hebben om al aan deze normen te kunnen voldoen.

De bemoedigende houding is een vorm van verantwoordelijk houden, maar niet een vorm van verwijt. Verwijt vereist dat de persoon laakbaar is, wat op zijn beurt weer vereist dat de persoon de capaciteiten heeft om morele normen na te leven. Maar de bemoedigende houding vereist dat de persoon verantwoordelijkheid draagt voor zijn eigen ontwikkeling, wat op zijn beurt weer vereist dat de persoon in potentie de morele normen kan naleven. Beide houdingen behelzen dus een vorm van verantwoordelijk houden. Dit in tegenstelling tot de objectieve houding, van waaruit iemand in het geheel niet verantwoordelijk wordt gehouden.

Ik heb hierboven beargumenteerd dat de bemoedigende houding gepast kan zijn wanneer de persoon zijn of haar vaardigheden om aan normen te voldoen nog moet en kan ontwikkelen. Maar een verdere toevoeging is noodzakelijk. Een baby heeft natuurlijk ook de potentie om 
bepaalde morele normen van onze samenleving na te kunnenleven, maar we kunnen deze potentie (nog) niet helpen te verwerkelijken door een moreel gesprek met de baby aan te gaan en een beroep te doen op haar leervermogens. De baby begrijpt niet wat morele normen zijn, en kan nog niet weten hoe ze zichzelf kan inzetten om in de toekomst aan die normen te voldoen.

Wanneer we een bemoedigende houding jegens iemand innemen is het dus niet alleen belangrijk dat we in de ander een potentie zien om in de toekomst aan bepaalde morele normen te voldoen, we zien die ander vanuit deze houding ook als iemand met wie we hierover een gesprek kunnen voeren en op wie we een beroep kunnen doen om zijn of haar eigen leervermogens aan te wenden. De bemoedigende houding onderscheidt zich hierbij op drie belangrijke manieren van de objectieve houding.

Ten eerste zien we de ander vanuit deze houding als een lid van de morele gemeenschap. Denk terug aan het voorbeeld van de gemeenschap waarbinnen bergbeklimmen een belangrijke vereiste is. Wanneer iemand in die gemeenschap een beroep doet op een ander om te leren een berg te beklimmen, erkent ze diegene daarbij als een lid van die gemeenschap. Wanneer iemand geen lid is van deze norm-gestuurde gemeenschap, heeft het immers geen enkele zin om van haar te vragen aan die normen te leren voldoen. Iets soortgelijks geldt voor de bemoedigende houding ten opzichte van mensen die in onze samenleving nog niet aan de morele normen kunnen voldoen. De bemoedigende houding erkent de ander als lid van een gedeelde morele gemeenschap en als iemand met morele leervermogens. Een objectieve houding jegens iemand die wel onze normen deelt en kan leren om die na te leven zou deze persoon juist miskennen in haar lidmaatschap en haar potentie. Dit gebrek aan erkenning en betrokkenheid is op zichzelf moreel problematisch (Anderson \& Honneth 2005; Honneth 1996). Maar het heeft ook verdere nadelige gevolgen. Wanneer de persoon met potentiële capaciteiten niet als zodanig erkend wordt kan dit zijn of haar eigen geloof in deze capaciteiten ondermijnen. Het kan ook de motivatie wegnemen om je in te zetten voor het naleven van normen in de toekomst wanneer de ander je niet erkent als een lid van de morele gemeenschap waarvoor die normen gelden (McGeer 2014).

Ten tweede zien we de ander vanuit de bemoedigende houding als een gesprekspartner met wie we morele normen en de naleving ervan kunnen bespreken. Zoals ik aan het begin van dit paper liet zien, wordt de ander vanuit de objectieve houding niet als een morele gesprekspartner gezien, i.e., als iemand waarmee je kan discussiëren ('reason with') of ruziemaken ('quarrel with') (Strawson 2008: 10). Maar vanuit een bemoedigende houding, zie je de ander juist wel als een gesprekspartner. Wanneer iemand in 
reactie op het overschrijden van een morele norm op een bepaalde manier wordt gevraagd en aangemoedigd om dat in de toekomst niet meer te doen, dan zien we de ander daarbij niet slechts als iemand die gecontroleerd getraind moet worden om volgzaam te zijn, zoals we dat soms bij hele jonge kinderen en sommige dieren wel doen. Er vindt wel degelijk morele communicatie plaats wanneer iemand de ander vanuit een bemoedigende houding adresseert. Vanuit deze houding wordt het belang van morele normen aan de ander voorgelegd en wordt van de ander gevraagd om het belang van die normen en zijn eigen morele ontwikkeling in te zien. Deze houding wil dus via een gesprek tot moreel inzicht en morele motivatie komen. En daarbij kan de morele evaluatie van degene die een bemoedigende houding inneemt in principe ook betwist worden door degene jegens wie deze houding wordt ingenomen. Kortom, er is hierbij ruimte voor 'reasoning' en voor 'quarrelling'.

Ten slotte is er binnen deze houding ook ruimte voor emotionele betrokkenheid op de ander. Hoewel verwijtgevoelens ongepast lijken wanneer iemand nog onvoldoende in staat is om morele normen na te leven, betekent dit niet dat er geen enkele ruimte is voor andere vormen van emotionele betrokkenheid binnen de bemoedigende houding. Denk bijvoorbeeld aan de manieren waarop ouders soms boos worden op hun kinderen. Dit zijn vaak echte emotionele reacties op de normoverschrijding van het kind, en die emoties schemeren vaak ook door in de manier waarop een ouder het kind terecht wijst. Dit alles betekent echter niet dat het kind ook laakbaar is en deze boosheid is niet per se een 'verwijt-gevoel'. Deze boosheid wordt het kind niet nagedragen en we kunnen deze gevoelens niet omschrijven als typische vormen van verontwaardiging of wrok. Echter, wanneer we vanuit de bemoedigende houding een beroep op iemand doen die in staat is een gesprek over morele normen te voeren en die in potentie aan morele normen kan voldoen, dan kunnen gevoelens van boosheid of irritatie in reactie op normoverschrijdingen wel een belangrijke rol spelen (McGeer 2011).

Tijdens mijn onderzoek heb ik clinici in een derdelijns kliniek geïnterviewd over hun emotionele reacties op grensoverschrijdend gedrag van patiënten. Uit deze interviews bleek dat de geïnterviewde clinici in de meeste gevallen met een patiënt in gesprek bleven en emotioneel betrokken bleven. Ook wanneer de patiënt nog niet voldoende in staat werd geacht om bepaalde normen na te leven. De redenen die deze clinici gaven voor het ervaren en uiten van boosheid in reactie op normoverschrijdingen hebben niets te maken met laakbaarheid (Brandenburg, unpublished). 
De clinici benoemden bijvoorbeeld de waarde van 'jezelf blijven' in relatie tot de patiënt. Wanneer je helemaal voorkomt dat je geraakt kan worden door het problematische gedrag van een ander, dan zet je als het ware een masker op. Dit staat een therapeutisch effectieve relatie in de weg en is volgens deze clinici ook een miskenning van de ander als mens. Emotioneel betrokken blijven is dus van belang om ervoor te zorgen juist niet in een objectieve houding te vervallen. Behalve betrokkenheid, laten deze emoties volgens hen ook zien dat onze reactie op de ander een morele evaluatie betreft. Deze emoties zijn niet noodzakelijk gekoppeld aan de laakbaarheid van een persoon en hoeven niet altijd de vorm van verwijt aan te nemen, maar zijn wel een indicatie dat een grens is overschreden. Op deze manier kunnen gevoelde en geuite emoties belangrijke morele markeringen zijn, zonder daarbij ook vormen van verwijt te zijn. Een clinicus zei hierover bijvoorbeeld 'als ik helemaal niet boos word, denkt iemand misschien ook, oh dit is eigenlijk niet zo erg wat ik doe... dit is normaal' (Brandenburg unpublished). Dit onderzoek suggereert dat andere vergelijkbare emoties een rol kunnen spelen die erg veel lijkt op de rol die verwijtgevoelens spelen binnen de Strawsoniaanse theorie.

Sommige Strawsonianen, zoals McGeer, Vargas en Sie zouden nu kunnen zeggen dat de bemoedigende houding al een plaats heeft binnen hun theorie (McGeer 2011; Vargas 2013; Sie 2018). Volgens deze theorieën zijn emotionele vormen van verwijt gerechtvaardigd wanneer ze 'scaffolding' of 'moreel opvoedend' zijn. Maar bovenstaande vormen van terechtwijzen zijn strikt genomen geen vormen van verwijt. Het is belangrijk om dit verschil te markeren. De verwijt-scepticus zal bijvoorbeeld niet alle vormen van strenge terechtwijzing afwijzen, omdat zulke reacties soms gepast kunnen zijn wanneer de persoon in kwestie geen absolute vrije wil heeft. Alleen vormen van verwijt die we kunnen classificeren als verontwaardiging en diepe persoonlijke wrok zijn volgens de verwijt-scepticus altijd ongepast. Dit terwijl, volgens bovenstaande Strawsonianen, deze gevoelens wel gepast kunnen zijn wanneer iemand willens en wetens kwade wil jegens een ander heeft, of moreel onverschillig handelt ten dele omdat ze, volgens deze auteurs, in een dergelijk geval ook een moreel cultiverende rol hebben. De bemoedigende houding is geen vorm van verwijt en cultiveert morele vaardigheden zonder daarbij ook te oordelen dat de ander willens en wetens kwaad heeft gedaan en zonder de daarbij passende emoties van verontwaardiging en wrok te ervaren. Deze houding biedt als zodanig een belangrijke aanvulling op de Strawsoniaanse theorie.

Strawson schreef dat er een sterke link is tussen verontwaardiging en laakbaarheid. Volgens hem vinden we deze emotie een gepaste reactie 
wanneer de persoon laakbaar is. Wanneer de persoon nog niet aan morele normen kan voldoen, kunnen we volgens hem deze reactie daarom beter opheffen, want dan is verwijt ongepast. Mijn belangrijke kanttekening hierbij is dat we genuanceerder moeten zijn over wat het betekent om emotioneel betrokken te zijn in reactie op normoverschrijdingen. De bemoedigende houding staat tussen de verwijtende houding en een objectieve houding in. Deze houding wordt niet gekenmerkt door verwijtgevoelens, maar ook niet door een volledige opheffing van emotionele betrokkenheid in reactie op norm-transgressies.

De bemoedigende houding vindt het midden tussen een verwijtende houding en een objectieve houding en wordt gekenmerkt door erkenning van de ander als een lid van de gemeenschap met moreel leervermogen, het zien van de ander als een gesprekspartner, en door een emotionele betrokkenheid op de ander. Deze houding is gepast wanneer iemand in potentie aan morele normen kan voldoen, en zich kan inzetten om zich moreel te ontwikkelen in samenwerking en gesprek met een bemoedigende ander.

\section{Conclusie}

Soms zijn mensen uitgezonderd van morele verantwoordelijkheid voor norm-overschrijdend gedrag omdat ze de normen die ze hebben overschreden nog onvoldoende goed kunnen begrijpen of omdat ze zichzelf niet voldoende kunnen controleren in het licht van deze normen. In dit stuk heb ik bevraagd wat dit betekent voor de manier waarop we ons tot deze mensen verhouden.

Strawsonianen suggereren dat we een objectieve houding moeten innemen jegens iemand die niet aan onze morele normen kan voldoen. Maar Pickard heeft erop gewezen dat we in de psychiatrie mensen wel degelijk verantwoordelijk houden (Pickard 2013). Hoewel deze mensen geen verwijt verdienen kunnen ze volgens haar toch aan onze normen voldoen en daarom is het gepast hen wel verantwoordelijk te houden. Het lijkt erop dat het zowel bij Strawsonianen als bij Pickard vaak niet duidelijk is of we het hebben over 'geheel niet kunnen', 'in potentie kunnen', of 'nu al kunnen'.

Ik heb beargumenteerd dat wanneer iemand iets in potentie kan, zowel een objectieve houding als een verwijtende houding ongepast is. Ik suggereer dat we in plaats daarvan een bemoedigende houding innemen. Vanuit de bemoedigende houding zien we de ander als een gesprekspartner op wiens leervermogens we een beroep kunnen doen. Vanuit deze houding gaan we wel in gesprek met de ander, en kunnen we wel emotioneel 
betrokken zijn op de ander, maar deze houding wordt niet gekenmerkt door het maken van verwijten en de daarmee geassocieerde emoties. De bemoedigende houding biedt zo een cruciale aanvulling op de Strawsoniaanse theorie, en voorkomt dat deze voorschrijft dat we ofwel verwijten maken ofwel een objectieve houding innemen ten opzichte van een groep mensen die het eerste niet verdienen en van het laatste weinig beter worden.

\section{Bibliografie}

Anderson, J.H., \& Honneth, A. (2005) Autonomy, vulnerability, recognition, and justice, in: J. Christman \& J. Anderson (Eds.), Autonomy and the Challenges to Liberalism: New Essays. Cambridge: Cambridge University Press, pp. 127-149.

Brandenburg, D. (unpublished) Interview Data, available upon request.

Brandenburg, D. (2017) The Nurturing Stance: Making Sense of Responsibility without Blame, Pacific Philosophical Quarterly 99 (S1), pp. 5-22. https://doi.org/10.1111/papq.12210

Eshleman, A. (2016) Moral Responsibility, in: E. N. Zalta (Ed.), The Stanford Encyclopedia of Philosophy (Winter 2016). Stanford: Stanford University. <https://plato.stanford.edu/archives/ win2o16/entries/moral-responsibility/>

Hieronymi, P. (2016) Freedom, Resentment, and the Metaphysics of Morals. Manuscript under review.

Honneth, A. (1996) The struggle for recognition: The moral grammar of social conflicts. Cambridge, MA: MIT Press.

McGeer, V. (2011) Co-reactive attitudes and the making of moral community, in: R. Langdon \& C. Mackenzie (Eds.), Emotions, Imagination, and Moral Reasoning (1st edition). New York, NY: Psychology Press, pp. 299-326.

McGeer, V. (2014) P.F. Strawson's Consequentialism, in: D. Shoemaker \& N. Tognazzini (Eds.), Oxford Studies in Agency and Responsibility, Volume 2. Oxford University Press, pp. 64-92.

McKenna, M. (2012) Conversation and Responsibility. Oxford: Oxford University Press.

McKenna, M., \& Kozuch, Benjamin (2015) Free Will, Moral Responsibility, and Mental Illness, in: D.D. Moseley \& Gala, Gary (Eds.), Philosophy and Psychiatry: Problems, Intersections and New Perspectives. New York: Routledge, pp. 89-113.

McKenna, M., \& Russell, P. (Eds.) (2008) Free will and reactive attitudes: perspectives on P.F. Strawson's 'Freedom and resentment'. Farnham: Ashgate Publishing, Ltd.

Pereboom, D. (2001) Living without Free Will (1st edition). Cambridge, U.K. and New York: Cambridge University Press.

Pickard, H. (2013) Responsibility without blame: Philosophical reflections on clinical practice, in: Fulford, K.W., Davies, M., Gipps, R., Graham, G., Sadler, J., Stanghellini, G., \& Thornton, T. (Eds.), Oxford Handbook of Philosophy of Psychiatry. Oxford: Oxford University Press, pp. 1134-1154.

Pickard, H. (2015) Psychopathology and the Ability to Do Otherwise, Philosophy and Phenomenological Research 9o (1), pp. 135-163. https://doi.org/10.1111/phpr.12025

Shoemaker, D. (2015) Responsibility from the Margins. Oxford: Oxford University Press.

Sie, M. (2018) Sharing Responsibility: The Importance of Tokens of Appraisals to our Moral Practices, in: K. Hutchison, C. Mackenzie, \& M. Oshana (Eds.), Social Dimensions of Moral Responsibility. Oxford: Oxford University Press. 
Strawson, P.F. (1962) Freedom and Resentment, Proceedings of the British Academy 48, pp. 1-25. Strawson, P.F. (2008) Freedom and resentment and other essays. New York: Routledge.

Todd, P. (2016). Strawson, Moral Responsibility, and the 'Order of Explanation': An Intervention, Ethics 127 (1), pp. 208-240.

Vargas, M. (2013) Building Better Beings: A Theory of Moral Responsibility (1st edition). Oxford: Oxford University Press.

Wallace, R.J. (1996) Responsibility and the Moral Sentiments. Cambridge, MA: Harvard University Press.

\section{Over de auteur}

Daphne Brandenburg is promovenda aan de Radboud Universiteit en Macquarie University. Ze schrijft een proefschrift over de manieren waarop we opgroeiende kinderen, mensen met autisme, en mensen met borderline persoonlijkheidsstoornis wel en niet verantwoordelijk kunnen en mogen houden voor moreel problematisch gedrag. Ze publiceerde onder andere Brandenburg, D. (2016) Implicit attitudes and the social capacity for free will, Philosophical Psychology, 29(8) en Brandenburg, D. (2017) The Nurturing Stance: Making Sense of Responsibility without Blame, Pacific Philosophical Quarterly, 99(1). 